\title{
A Long-Distance Relationship: Staff Weapons as a Microcosm for the Study of Fight Books, c. 1400-1550
}

\author{
Iason-Eleftherios Tzouriadis \\ The Worshipful Company of Gold and Silver Wyre Drawers \\ Jacob Henry Deacon \\ Institute for Medieval Studies, University of Leeds
}

\begin{abstract}
The fifteenth-century fight book author Filippo Vadi wrote that the sword "is a cross and a royal weapon": this inherent chivalric symbolism associated with the sword has led to a wealth of scholarship on the weapon but seemingly at a cost to research into other forms of weaponry used in medieval and early modern Europe, particularly various typologies of staff weapons. ${ }^{1}$ This article presents an analysis of the appearance staff weapons in the heterogeneous fight book genre. It uses their limited appearance, in comparison to swords, as a means of creating a microcosm through which several questions about the wider fight book genre can be assessed.
\end{abstract}

Keywords - staff weapons, fight books, fighting system, martial arts, Historical European Martial Arts Studies, arms and armour, warfare

\section{INTRODUCTION: PROBLEMS OF TERMINOLOGY AND TYPOLOGY}

The aim of this article is to examine staff weapons in the context of the heterogeneous fight book genre as it pertains to the fifteenth and first half of the sixteenth centuries. Staff weapons offer a unique way of contextualising contemporary fight books due to their more limited presence and treatment in comparison to the almost ubiquitous appearance of different sword types. Studying staff weapons thus creates a lens through which one can carry out a more specific and sustained analysis of the genre. Isolating and approaching this microcosm of staff weapons within the wider genre further allows scholars to extract useful information about the weapon group itself, to ascertain how this information relates to the fight book corpus, and to highlight some of the problems in their research - the latter of which this article will address first.

The study of staff weapons in the fifteenth and sixteenth centuries of western Europe presents a certain anomaly when compared to research into other weapon groups. Modern scholarship on arms and armour, in addition to broader studies of warfare during the period, often overlooks or minimalises the use and importance of staff weapons; many

\footnotetext{
1 "Piglia la spada in mano uirilmente perch(e) le croce \& e un arma reale". Roma, Biblioteca Nazionale Centrale di Roma, MS Vitt.Em.1324, fol. 4v. 
of these often characterise staff weapons as the arms of peasants and local militias. ${ }^{2}$ This characterisation has, however, been disputed and staff weapons are also correctly acknowledged as the tools of professional soldiers such as the German Landsknecht and Swiss Reisläufer. ${ }^{3}$ Modern scholars, it should be noted, were not the first writers to give staff weapons such a superficial treatment, and the same pattern can often be observed as an echo of the views espoused by historical fight book authors themselves: Sydney Anglo, for example, has previously described Agrippa's (d. 1600) coverage of staff weapons in his 1553 Tratto di Scientia d'Arme as being so perfunctory that it ought to be interpreted as a sign of his dislike of the weapon group, especially given his comparison between staff weapons and the two-handed sword, a weapon which he considered "too crude for serious analysis". ${ }^{4}$ Generally speaking, staff weapons are academically overlooked as a subject in themselves and also as source material for other research. The dismissal of this weapon group is directly linked to the importance and tradition of the sword, both as a weapon and also as a historical symbol of status and power, resulting in an understandable primacy for the sword in modern scholarship..$^{5}$ Another convincing explanation for this lack of focus on staff weapons can also be found when working with written primary sources - the central material for much traditional, disciplinary history where they are also underrepresented in comparison to their actual state of use. Narrative accounts such as chronicles and romances rarely mention staff weapons in much detail, and more detailed mentions are often located in muster rolls and inventories of the period; these can often be difficult to locate in local archives. ${ }^{6}$ Where staff weapons do appear in

2 For examples see the following; Strickland (ed.), Armies, Chivalry and Warfare in Medieval Britain and France; Curry and Hughes (eds), Arms, Armies and Fortifications in the Hundred Years' War, Blair, European and American Arms; Oakeshott, European Weapons and Armour, Rimer, 'Weapons'; Nicholson, Medieval Warfare; Contamine, Guerre, état et sociétè à la fin du Moyen Age; Mallet and Shaw, The Italian Wars, 1494-155.

3 Tlusty, The Martial Ethic in Early Modern Germany; Hall, Weapons and Warfare in Renaissance Europe; Hale, Artists and Warfare in the Renaissance.

4 Anglo, The Martial Arts of Renaissance Europe, p. 148; Camillo Agrippa, Tratto di Scientia d'Arme, pp. 23-24.

${ }^{5}$ A recent series of exhibitions, conferences, and publications from the Deutsches Klingenmuseum in Solingen, Germany, have dedicated themselves to assessing the sword through multidisciplinary approaches. For the catalogue and conference proceedings see Grotkymp-Schepers et al. (eds.), Das Schwert: Gestalt und Gedanke, and Deutscher, Kaiser and Wetzler (eds.), The Sword: Form and Thought.

${ }^{6}$ In the case of England, for instance, two excellent examples showing the widespread nature of staff weapons are to be found in the 1457 Bridport muster roll and the inventory of King Henry VIII. See Dorchester, Dorset History Centre, DC/BTB/FG/3 and The Inventory of King Henry VIII: The Transcript. For a transcription and overview of the muster roll see Richardson, 'The Bridport Muster Roll of 1457'. A difference can be seen in fifteenth- and sixteenth-century battle narratives in chronicles wherein the latter are more inclined to focus on the exploits of infantry and their bloody battles. The persisting problem for historians, however, is located in the precise identification of the staff weapons used by infantry because of the vague terminology used to describe their equipment. In the case of romances, knightly protagonists are often presented as wielding sword and lance; the most notable exception is found in the macabre personage of the Green Knight. For further analysis of staff weapons in narrative sources see Troso, Le armi in asta, 
great numbers, however, is in artistic representations of military and martial topoi; from 1400 to 1600 a staggering variety of staff weapons are featured in a number of thematic cycles ranging from scenes of religious and military importance to portraits and representations of civic life. Fight books, however, it must be said, appear to follow the same trend as other literary genres. ${ }^{7}$

In order to fully develop some of the ideas in this article it will be necessary to provide a definition of what constitutes a staff weapon; two reoccurring problems in the study of this weapon group are the inconsistent terminologies and boundaries for weapon groups, both of which are rarely justified. ${ }^{8}$ Staff weapons have been defined by Iason-Eleftherios Tzouriadis in his doctoral research as two-handed weapons used on foot which, depending on their type, can have different offensive uses including thrusting, cutting, bludgeoning, pulling, and throwing. They can be edged or blunt. Staff weapons mainly consist of two parts: a long wooden shaft that is surmounted by a metal head. Additional parts, such as reinforcing metal strips called langets, are sometimes added to the shaft as part of the finishing process. Occasionally the shaft is made of steel or other metals, and the head itself can also include wooden parts. ${ }^{9}$ The length of the shaft varies depending on the category of the individual staff weapon and can range from one up to six metres. Additional parts may be attached to the weapon; these can include a spike on the lower

pp. 85-96, and Tzouriadis, 'The Typology and Use of Staff Weapons in Western Europe c. 1400 c. $1550^{\prime}$, pp. 33-35.

${ }^{7}$ It is interesting to note that the lack of emphasis on staff weapons in fight books appears to have had a knock-on effect on the modern day practice of Historical European Martial Arts where it is the sword that is most popular among practitioners. Staff weapons sometimes feature as a secondary or tertiary subject of study. This is likely due to the aforementioned symbolic appeal of the sword although another more practical reason is the comparatively low number of suitable staff weapon simulators available for purchase (although since this paper was first delivered in 2017 they are becoming more widespread). Even weapons made from "safer" materials than steel, however, such as rubber or wood, still have the potential to deal serious damage to practitioners in free-play or sparring: perpendicular strikes alongside the axis of the shaft deliver blows with little elasticity and energy distortion which cannot be reasonably prevented by the safety gear worn by most practitioners.

8 A variety of both specialised and non-specialised works in the past century have dealt with the nomenclature of staff weapons. The inherent problem of these studies - whether writing in English, Italian, German or French, or even using terminology from one language whilst writing in another - is to be found in the inconsistency of the terminology used to describe the same object. Authors such as Stone, Ellehauge, Troso, and Waldman have all discussed the problem of terminology but it is nearly impossible to produce a finite solution. The inconsistencies among even these specialised works only serve to emphasise the problem. See Stone, A Glossary of Construction, Decoration and Use of Arms and Armor; Ellehauge, Certain Phases in the Origin and Development of the Glaive; Troso, Le armi in asta: Delle fanterie europe; Waldman, Hafted Weapons in Medieval and Renaissance Europe.

${ }^{9}$ Examples of this are usually percussive weapons such as simple and military Morgensterne and military flails. For some extant examples see: Military Morgenstern, Vienna, Heeresgeschichtliches Museum, 126.207; simple Morgenstern, Leeds, Royal Armouries, VII.1366. For a visual representation of these weapons from the period discussed in this article see Hans Holbein the Younger, The Capture of Christ, Kunstmuseum, Basel. 
end of the shaft, one or two protective hand-guards, a means of safely securing the head to the shaft, or any combination thereof. The utility of staff weapons revolves around the reach that they provide to the user, as well as the different offensive potentials based on the technical characteristics of the weapon's head. Their versatility depends on these characteristics and can potentially allow the user to perform a succession of hits with the consecutive use of different features, or execute more complex actions such as disarming, tripping, tangling, and pushing. The aim of the wielder is to increase their threat by fighting at range in order to utilise the increased power deriving from the kinetic energy produced through perpendicular thrusts and centrifugal strikes. Staff weapons can be devastating against both infantry and cavalry, and many were designed to penetrate armour. Their length allows the user to fight enemies on foot from distance, withstand a cavalry charge, or even to cut down a mounted opponent. At the same time their increased length was also a source of weakness as they could not be used as effectively in close quarters. ${ }^{10}$ Spears and pikes also belong to this weapon but are, however, largely excluded from our article's analysis in order to allow for a focus on the most popular and complex weapons that appeared in fight books such as bills, halberds, spiedos (in this context winged spears and the chamve-souris or pipistrello), partisans, glaives, scythes, flails, and axes. $^{11}$

\section{APPEARANCES AND PATTERNS OF STAFF WEAPON USE IN FIFTEENTH-CENTURY FIGHT BOOKS}

For all the numerous typologies of staff weapons that appear in fight books, it is only the pollaxe/axe-hammer that is treated with any regularity in the fifteenth century. As such it is worth providing a specific definition of the term. Axe, and variants of the word, refer to the wider group recently categorised by Tzouriadis as axe-hammers, but can also be categorised as pollaxes. ${ }^{12}$ Weapons of this group are composed of two or three different features taken from a bigger list which includes an axe blade, a long hammer-head, an angled or curved horizontal spike called a beak, a coronel-shaped hammer (a hammer that

\footnotetext{
10 Tzouriadis, 'The Typology and Use of Staff Weapons in Western Europe c. 1400 - c. 1550', pp. 4-6

11 The nomenclature of the spiedo varies greatly depending on region as well as in modern bibliography. For further discussion and examples of this problem see Tzouriadis, 'The Typology and Use of Staff Weapons in Western Europe c. 1400 - c. 1550', pp. 138-43, and Troso, Le armi in asta: Delle fanterie europe, p. 99.

12 Tzouriadis, 'The Typology and Use of Staff Weapons in Western Europe c. 1400 - c. 1550', pp. 226-43. The definition of weapons in Tzouriadis' axe-hammer group is a point of difference between the two authors. Tzouriadis advocates for the inclusion of several axe types, including weapons often referred to as lucerne hammers and bec-de-corbins as sub-groups, under the wider label of his own creation, axe-hammer. Deacon, on the other hand, is against the addition of additional terminology for studying an already lexicologically-crowded subject, and instead prefers 'pollaxe' as a term for all such weapons.
} 
ends in three or four prongs), and a vertical spike of various sizes. The rest of an axe's appearance and construction conform to the definition provided in the introduction.

The popularity of the axe within fifteenth-century fight books is arguably due to its reputation as the most chivalric of staff weapons; it was, for example, a consistently popular choice in the numerous pas d'armes of the fifteenth century. ${ }^{13}$ Thus, for audiences with an interest in displaying their ownership of an ennobling martial art, as outlined by Jeffrey Forgeng, it made commercial sense for fight book authors to prioritise the depiction of the axe over other staff weapons. ${ }^{14}$ Other, less chivalric staff weapons could be ignored or glossed over due to similar technical features and approaches to their use; Hugo Wittenwiller's fifteenth-century material on fighting with staff weapons, for example, describes itself as focusing on "the spear and the staff" against a halberd, but subsequently mentions the spear almost exclusively. ${ }^{15}$

Staff weapons, however, can be compared in this manner not just to each other but also other weapon types. There is a practically ubiquitous trend observable in early fight books which indicate that staff weapons ought to be used in a similar manner to swords. This pattern exists across the multiple addressees and communication strategies of these heterogenous texts, and whether or not they depict armoured or unarmoured combat. One example can be seen in the fourteenth-century fight text in Germanisches Nationalmuseum Hs. 3227a, which contains a single folio pertaining as to how to fight with the staff. ${ }^{16}$ The anonymous author indicates that the art of fighting with the staff is taken from the sword and that however one fights with the sword they should also use the staff. Combat using the staff also adheres to the same principles of the before and after, courage, quickness, cunning, and prudence. ${ }^{17}$ The same notion can be seen in the works of Fiore dei Liberi in early fifteenth-century Italy when focusing on his most complete manuscript, MS Ludwig XV 13, also known as the Getty. In his section on the use of the axe in armour Fiore depicts six poste and eight plays. ${ }^{18}$ Variations of these poste, or positions, can be seen earlier in the manuscript. Posta breve la serpentine, posta de vera croce, and porta di ferro mezana are all found on the folios dealing with the use of the sword in armour, whilst the remaining poste are treated in the section describing unarmoured

${ }^{13}$ For the role of staff weapons in fifteenth- and sixteenth-century tournament foot combat see Tzouriadis, 'The Foot Combat as Tournament Event: Equipment, Space and Forms', pp. 168-68. One often-studied example is the series of combats that took place at Smithfield in 1467 between Anthony Rivers, Lord Scales and Antoine de Bourgogne, the Bastard of Burgundy. There are several eyewitness accounts that attest to the ferocity of the combat fought with axes. For an edition of selected manuscript accounts see Moffat, 'The Medieval Tournament', pp. 323-34 and pp. 337-38. For an analysis of their reliability see also Anglo, 'Anglo-Burgundian Feats of Arms'.

14 Forgeng, 'Owning the Art', p. 172.

15 “Mit dem spies und mit der stangen”. München, Bayerische Staatsbibliothek, Cgm 558, fol. 130r. 16 The dating of this manuscript to the late fourteenth century (c. 1389) is the most likely theory but not the most definite. See Burkart, 'The Autograph of an Erudite Martial Artist', p. 453.

17 Nuremberg, Germanisches Nationalmuseum, Hs. 3227a, fol. 78

${ }^{18}$ Los Angeles, J Paul Getty Museum, MS Ludwig XV 13, fols 35v-37r. 
combat with the sword. ${ }^{19}$ The techniques are likewise treated in a similar manner, and Fiore references using either a sword or axe to perform similar techniques when he describes porta di ferro mezana. ${ }^{20}$ Despite the occasional difference they are, overarchingly, very similar. Such notions are reinforced due to the fact that the Getty manuscript also includes multiple instances of a weapon which Fiore says passes for a sword and an axe, called by him a spada-azza, further demonstrating a common approach in how these arms can be used (see Fig. 1). ${ }^{21}$

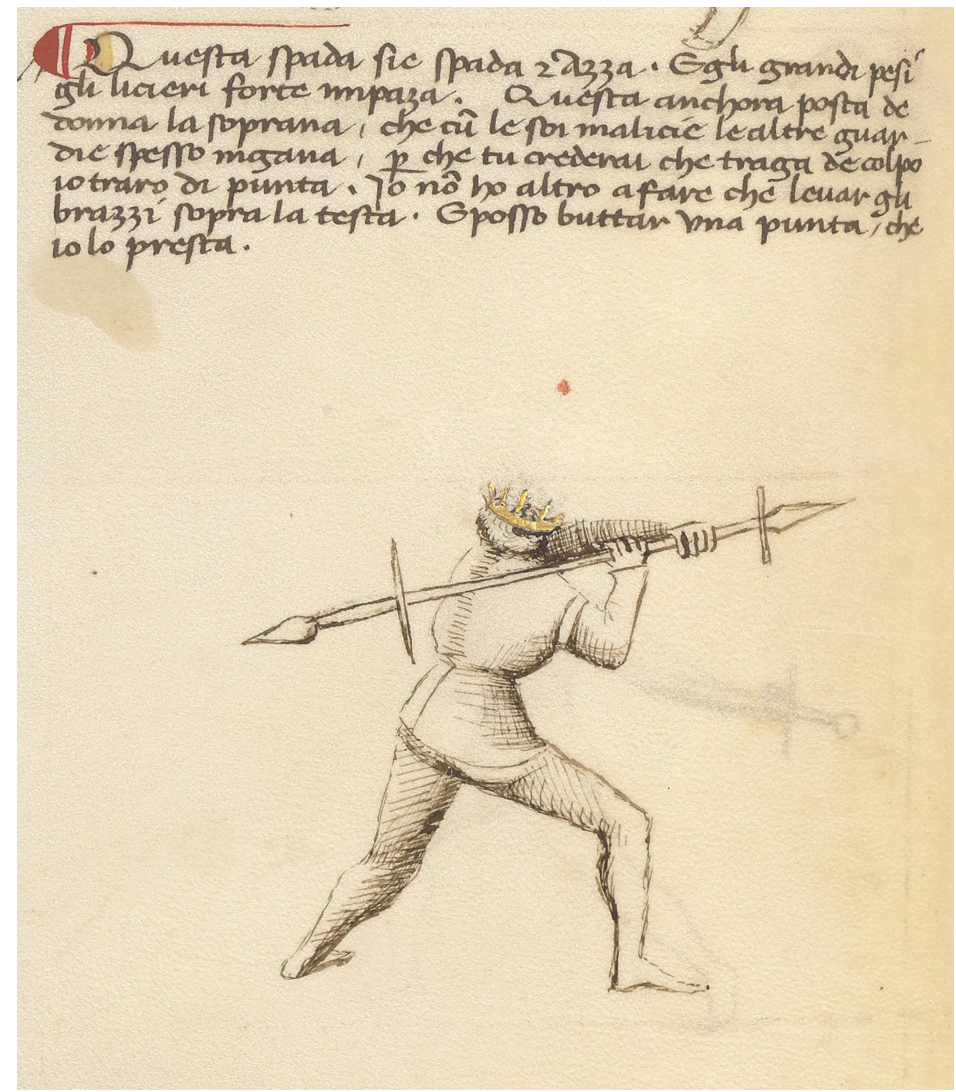

Fig. 1. One of several illustrations of Fiore dei Liberi's spada-azza, a weapon that he states can be used both in and out of armour and to great effect against lighter weapons. Fiore dei Liberi, Fior di Batagglia, c. 1410, Los Angeles, J Paul Getty Museum, MS Ludwig XV 13, fol. 22".

This theme of a common approach to fencing informed by staff weapons is further present in a fifteenth-century text produced for the Burgundian court, Le Jeu de la Hache, the most

\footnotetext{
${ }_{19}$ MS Ludwig XV 13, fol. 32v and fols 22r $-24^{\mathrm{v}}$.

20 MS Ludwig XV 13, fol. 35v .

21 A second example can be seen later in the manuscript; MS Ludwig XV 13, fol. 35 .
} 
detailed fight book to broach the use of staff weapons and specifically the axe. ${ }^{22}$ Several theories have been proposed as to a more precise dating of the anonymous manuscript, the problematic dating of which corresponds to the difficulties of dating staff weapons from the fifteenth century. The earliest of these assignations is by Sydney Anglo, who believes it was produced in the first quarter of the fifteenth century. ${ }^{23}$ Ken Mondschein has since argued that it was likely written by Ambrose, a Milanese master hired by Duke Philip the Good in $1434 .{ }^{24}$ Even more recently, however, a comprehensive analysis of the language, vocabulary, and other factors by Olivier Dupuis and Vincent Deluz suggests a dating between 1460 and $1485 .{ }^{25}$ Although its martial content means that it could be dated from anywhere between the first and last quarter of the fifteenth century, it is likely that the dating proposed by Dupis and Deluz is more accurate due to its alignment with an increasing use and appearance of axes and staff weapons in other contemporary sources from the latter fifteenth century. ${ }^{26} \mathrm{Le}$ Jeu de la Hache's creation of a relationship between learning to fight with the axe and other weapons is the most explicit, as seen in the author's exhortation that "let every man noble of body and courage, naturally desire to exercise and enable himself in a virtuous and honourable occupation. And principally in the noble feat of arms, that is to say in axe-play, from which proceed and depend several weapons above-named". ${ }^{27}$ Supposedly proceeding from axe-play and listed here are the half-pike, the dagger, the greatsword, and the shortsword. It is interesting to note, however, that whilst all of these texts agree on a relationship between the pollaxe and other weapons in forming one's martial education, they differ in that they view this relationship from different perspectives. It is $L e$ Jeu de la Hache which, more so than any other fight book, advocates for the axe as the premier weapon, but the more detailed treatment of the longsword in Fiore's corpus attests that he believes the reverse of this, and that skill at the pollaxe could be gained from learning how to fight with the two-handed sword; the same is also clearly seen in the fight book content in Hs. 3227a.

A later Italian writer who also discusses staff weapons is Filippo Vadi. ${ }^{28}$ Seeking to use his work to establish patterns in staff weapons in the late fifteenth century, however, is a problematic approach: in several places, including his treatment of the axe, his fight book

22 Paris, Bibliothèque nationale de France, MS Français 1996.

23 Anglo, 'Le Jeu de la Hache'.

24 Mondschein, 'The Italian Schools of Fencing', p. 300.

25 Dupuis and Deluz, 'Le Jeu de la Hache', pp. 25-26.

26 A considerable instance of this is in the sizeable body of literature detailing the opulent Burgundian pas d'armes, especially in accounts by Georges Chastellain (d. 1475) and Olivier de la Marche (d. 1502). A particular exemplar of fighting with the pollaxe at these pas d'armes was Jacques de Lalaing. For the pas d'armes and tournament career of Jacques de Lalaing see Planche, 'Du tournoi au théâtre en Bourgogne'.

27 "Et pour ce que tout homme noble de corps et de courage naturelment desire d'excerciter et habilliter sa personne en occuppacion vertueuse et honnourable, et principalment ou noble fait d'armes, c'est assavoir au jeu de la hache dont procedent et despendent plusieurs glaives dessus nommez". Dupuis and Deluz, 'Le Jeu de la Hache', p. 33.

${ }^{28}$ MS Vitt.Em.1324, fols 24r-25r. 
is little more than a rewrite of one of Fiore dei Liberi's manuscripts. ${ }^{29}$ Although Mondschein has noted several differences between their approach to swordplay, when it comes to the various poste and techniques for axe-play (four of which are presented for each) only a few differences are discernible. ${ }^{30}$ Those which do exist are minor. Vadi indicates a slightly different position for the posta sagitaria and posta di croce than Fiore's equivalents. Three of the four techniques are also identical; there is only one from Fiore's work that Vadi has not included, and this has been replaced with a grappling technique unseen in any of Fiore's plays with the axe (see Fig. 2).

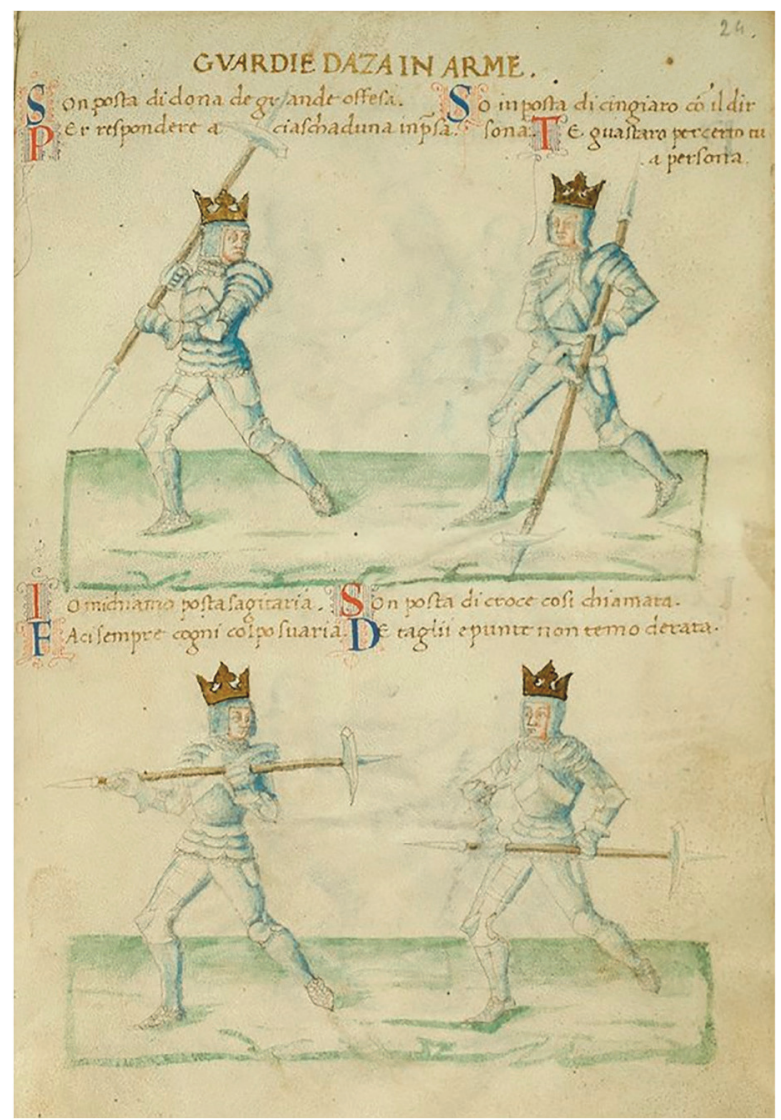

Fig. 2. Two of Filippo Vadi's plays of the axe in armour. The first technique is original to this manuscript, whilst the second has its origins in the works of Fiore dei Liberi. Filippo Vadi, Liber de arte gladiatoria dimicandi, 1482-86, Roma, Biblioteca Nazionale Centrale di Roma, MS Vitt.Em.1324 25r.

29 Anglo, The Martial Arts of Renaissance Europe, p. 132.

30 Mondschein, 'The Italian Schools of Fencing', p. 298. 
When comparing the uses of staff weapons in fight books, particularly axes, it is possible to ascertain patterns in how authors believed they were best used as weapons. In a quantitative comparison of Le Jeu de la Hache and works by Hans Talhoffer, two of the most detailed treatments of the axe, it becomes apparent that both authors strongly rely on using the thrusting elements of the weapon. This is the most common attack either prescribed or depicted in Le Jeu de la Hache and the 1459 fight book of Talhoffer, the former even suggesting one thrust is a "good and sure one to pursue, because it cannot do you any harm [by attempting it]". ${ }^{31}$ Indeed, the percussive aspect is rarely used, whether in Le Jeu de la Hache or the 1459 or even 1467 manuscript. ${ }^{32}$ One can also comment on Talhoffer's proclivity to ignore both percussive and thrusting elements of his axe, and instead rely on using it to hook, throw, and unbalance an opponent; in his 1467 fight book nearly three quarters of the illustrations show a disarm, a hook, or a throw (see Fig. 3). Unfortunately, this approach is not without problems; a larger number of techniques does not necessarily imply a favoured or superior strategy, rather perhaps a wider range of possibilities in how that part of the weapon can be used.

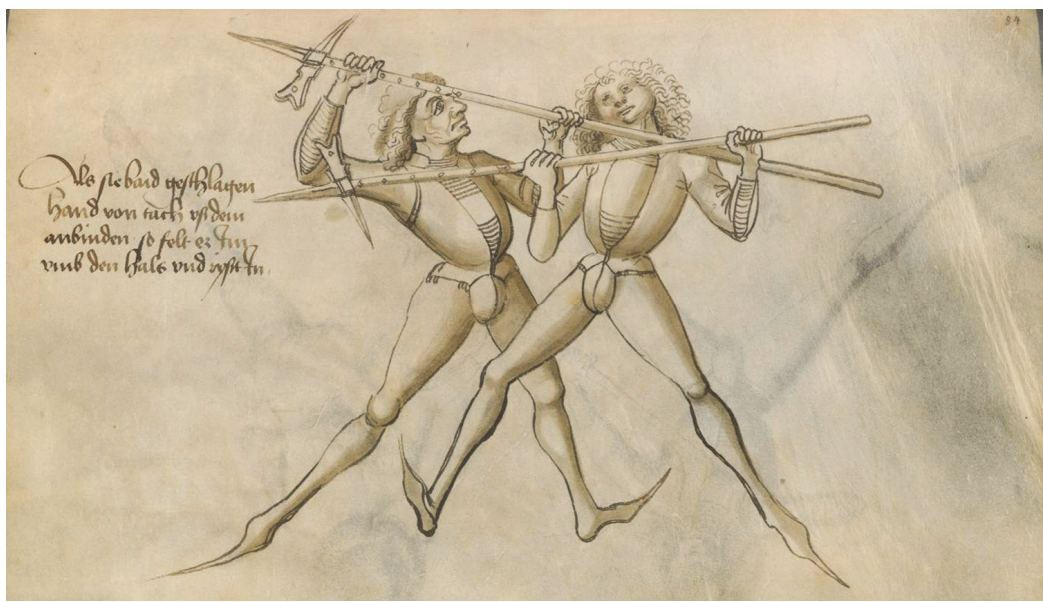

Fig. 3. One of several examples of the pollaxe being used in Talboffer's 1467 manuscript to book and throw an opponent. Hans Talhoffer, 1467, München, Bayerische Staatsbibliothek, Cod.icon 394a, fol. $43^{v}$.

The diversity of techniques between sources such as Le Jeu de la Hache and Talhoffer is indicative of the martial contexts with which the authors of fifteenth-century fight books were concerned. Le Jeu de la Hache is addressed to a champion, and has a high proportion of thrusts directed at the face - indicative of intent to wound and a more serious context - but the author also offers several ways of ending the combat non-lethally; nearly half of

\footnotetext{
31 "Et ce coup est bon et seur à poursuivir, car il ne vous en puet mesadvenir", Dupuis and Deluz, 'Le Jeu de la Hache', p. 37; For Talhoffer's 1459 pollaxe material see Købnhavn, Det Kongelige Bibliotek, MS Thott. $290.2^{\circ}$, fols $71^{\mathrm{v}-74^{\mathrm{v}}}$ and $131^{\mathrm{v}-137 \mathrm{v}}$.

32 For Talhoffer's 1467 pollaxe material see München, Bayerische Staatsbibliothek, Cod.icon 394a, fols $41^{r}-53^{r}$.
} 
the various techniques end with the opponent either disarmed or thrown. ${ }^{33}$ It is worth noting that Daniel Jaquet has recently proposed a similar idea for a multitude of martial contexts in arguing for a playful interpretation of the Anonimo Bolognese. ${ }^{34} \mathrm{~A}$ throw or disarm could of course signal the end of the combat but it could also lead to further fighting; Talhoffer shows several instances in which combatants have discarded their weapons and resorted to grappling on the ground and using daggers to kill one another. ${ }^{35}$ A not too dissimilar end is shown by Paulus Kal, where the defeated and downtrodden opponent is struck by the axe of his upright opponent (see Fig. 4). It could also be argued, however, that the heightened violence is a commercial factor which is used to pique the interest of the reader, both in the context of the fight book genre and also fifteenth/sixteenth-century art, and thus the violence displayed is not necessarily indicative of martial context. ${ }^{36}$

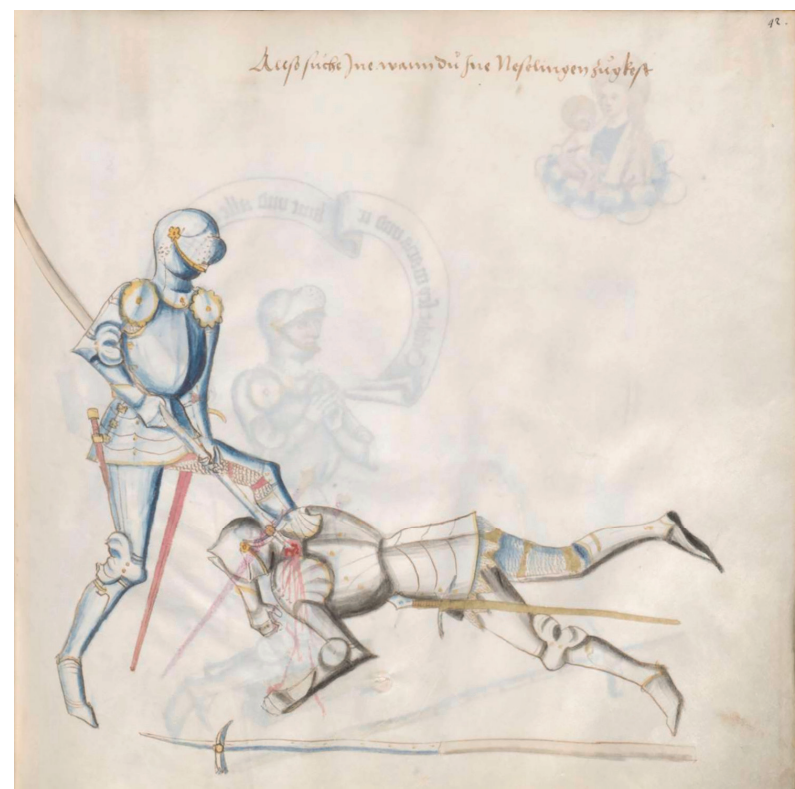

Fig. 4. Paulus Kal's section on the use of the pollaxe finishes with this illustration showing how the weapon may be used to deliver the coup de grâce. Paulus Kal, c. 1470, München, Bayerische Staatsbibliothek, Cgm 1507, fol. 42r.

\footnotetext{
33 Dupuis and Deluz, 'Le Jeu de la Hache', p. 34.

34 Jaquet, 'The Plays with the Axe in Armour of the Anonimo Bolognese (1510-1515)', pp. 111-12. 35 MS Thott.290.2 $2^{\circ}$, fols $136^{\mathrm{r}}$ and $137^{\mathrm{v}}$.

36 Kleinau, 'Visualised Motion', pp. 111-13; See also Eco, On Ugliness. In his book Eco discusses the unconventional and often uncomfortable themes in art that can be characterised as ugly, violent, or obscene. He explores how they both appeal to the viewer and also belong to a wider aesthetical process that changed throughout history as part of artistic processes.
} 
It may strike one as unusual that even though staff weapons predate the widespread use of the two-handed sword, several writers advocate that the use of staff weapons is derived from this later weapon. This is most likely due to the chivalric primacy of the sword and its symbolic status above all other medieval weapons. Although it is not uncommon to see chivalric icons such as the Nine Worthies (and the Nine Worthy Women) depicted with them, a treatment of staff weapons in a chivalric context is beyond the confines of this article and will have to be explored more in future research. Even though staff weapons predate the primacy of the two-handed sword in late medieval Europe it is easy to understand why authors such as Vadi, who advocate that the sword is "a cross and a royal weapon", give this theoretical superiority to swords..$^{37}$ This can, furthermore, be linked to aforesaid arguments regarding the dominance of the axe in fight books (amongst staff weapons); as readers have an interest in acquiring or claiming ownership of an ennobling skill, so fight books fulfil this role by presenting a weapon loaded with symbolism as key to the art. ${ }^{38}$

As mentioned in the introduction, the limited treatment of staff weapons in fight books allows for them to be used in creating a microcosm to study the wider genre. An example of this can be seen when considering the communication strategies of fight books. The most popular means of inscribing, describing, and codifying embodied knowledge - a methodological approach to defining communication strategies pioneered by Daniel Jaquet - are all present in fifteenth-century texts dealing with staff weapons. ${ }^{39}$ They can additionally be used as a lens through which to examine the wide-ranging purposes of fight books. A detailed study of this latter consideration lies, however, outside the scope of this article. ${ }^{40}$

One of the finest examples of a fight book containing an inscription (the documentation of practice without evidence of didactic intent) of staff weapon use is in the Liber de Arte Gladiatoria of Filippo Vadi. The content that explicitly deals with the use of staff weapons is presented with seemingly little interest in transmitting the knowledge from page to practice. This can be seen both in his guards of the axe in armour and subsequent techniques: there are four of each. Vadi's guard descriptions relate to the reader their name, an (apparent) characteristic, and an illustration. The problem is, however, that this does not express when the guard should be used, or how it aims to accomplish its promises: the archer's stance, for example, claims to deflect all blows, whilst the cross stance similarly supposedly does not fear any strike of edge or point (these are also

37 "Piglia la spada in mano uirilmente perch(e) le croce \& e un arma reale". MS Vitt.Em.1324, fol. 4 v.

38 Forgeng, 'Owning the Art', p. 172; for how the act of moving in a specific manner contributes to creating noble status, see Wetzler, 'Überlegungen zur europäischen Fechtkunst', p. 73.

39 The inscription, description, codification approach to fight books is devised by Daniel Jaquet. For his approach to the subject see Jaquet, 'Martial Arts by the Book'.

${ }^{40}$ For a more thorough treatment of the purposes of fifteenth-century fight books see Deacon, 'Prologues, Poetry, Prose and Portrayals'. 
practically identical descriptions that highlight the invulnerability of the practitioner to attacks). ${ }^{41}$ These descriptions are thus alike in ascribing defensive qualities to the guards, but fail to further expand on what exactly this means. The same is true of the techniques. Those shown illustrate the successful conclusion to four different techniques but there is no explanation in the accompanying text that aids in expounding their meaning; one technique is briefly summarised as "I am in the boar's guard, as the saying goes. I will certainly damage your person". ${ }^{42}$

The clearest example of a fifteenth-century text which conforms to the description element of Jaquet's tripartite approach, defined as "the documenting of practice with evidence of didactic intent", is the aforementioned Le Jeu de la Hache. ${ }^{43}$ The anonymous author presents the material in a didactic manner that is superior to any other fifteenthcentury text dealing with staff weapons, and is arguably even more pedagogically inclined than any other fifteenth-century fight book in general, as seen in the following example:

When someone strikes you by means of a tour de bras, right-hander to righthander, if you have the cross in front, you can step forward with your left foot, receiving his blow by picking it up the axe's tail; in a single movement strike downward to make his axe fall to the ground. And from there, following up one foot after the other, you can thrust him with the said tail, sliding it through the left hand, at the face, or wherever seems good to you. Or you can strike him by means of a tour de bras to the head. If you have the tail forward, you can do it the same way without moving. Again, if you have the cross in front, as above, you can receive the said blow with the tail of your [axe] by stepping backward. From all three covers, you can give the said blows by means of tours de bras and the tail. ${ }^{44}$

The problems of recreating historical fighting systems from fight books is well documented in recent scholarship: an entirely accurate recreation of these lost arts is, indeed, lost to us. ${ }^{45}$ The clear way in which the author of Le Jeu de la Hache presents their

41 MS Vitt.Em.1324, fol. 24r.

42 "So in posta di cingiaro con il dir sona. Te guastraro per certo tua persona". MS Vitt.Em.1324, fol. 24 v.

43 Jaquet, 'Martial Arts by the Book', p. 44.

44 "Item quant on vous donra de tour de bras droittier à drottier, se vous avez la croix au devant, vous pouez marchier avant du pié gauche en luy recevant son coup en cueillant de la queue de la hache. D'une venue ferez contre bas pour la luy faire cheoir à terre. Et de là, pouez, en marchant l'ung pié apres l'autre en suyvant, luy baillier d'estocq de ladite queue en coulant par la main gauche au visage ou là où bon vous samblera, ou luy baillier à tour de bras sur la teste. Item se vous avez le queue devant, le pouez pareillement faire sans vous bougier. Item encore se vous avez la croix devant comme dessus, pouez recevoir ledit coup de la queue de la vostre en desmarchant en arriere. De toutes les trois couvertes pouez donner lesdits coups de tours de bras et de l'estocq de la queue". Dupuis and Deluz, 'Le Jeu de la Hache', p. 34.

45 Burkart, 'Limits of Understanding in the Study of Lost Martial Arts'. 
approach to fighting with the axe, however, ought not to be understood as anything other than didactic, even if it is missing (potentially) important pedagogical aspects such as illustrations. Every step of the technique is described, from how one should stand to receive the strike, to where one's own attack or counter-attack should be directed. The author furthermore provides the reader with multiple options as to their response. Likewise, while there is specialised terminology used throughout to denote specific parts of the axe, such as queue and croix, their meanings can be inferred from the source itself. As such, whilst Le Jeu de la Hache was unlikely to have been used to educate a novice, or even inform a skilled individual's practice (the most recent analysis of the text by Dupuis and Deluz does not suggest why it was produced), as is the case with many other contemporary manuscripts dedicated to the practice of arms, it nonetheless reads as if it could be used in this way.

A more cryptic account of staff weapon use is to be found in a brief fifteenth-century text from England, roughly contemporaneous with Le Jeu de la Hache, held at the British Library. The martial content, which includes a single folio pertaining to the two-handed sword and the staff, is part of a twelve-leaf manuscript that was later compiled alongside five other medieval items. ${ }^{46}$ This third fight book is an example of how codification is used to record martial arts knowledge. Such texts are defined by Jaquet as those which document practice by means of encryption. ${ }^{47}$ The entirety of the staff weapon content text is reproduced below:

The fyrst pointe is a florysh about the fynger pe nexte florysh is abowte pe hande And thanne iij quateres And a rownde and ii rakes \& ij funes iij quateres closede staffe $\mathrm{A} j$ rounde war hym your armes be hynde

\& than ij hawkes for pe wrong syde (bryng)

A fune for hym in pe tother syde And pe

herte pe fote pe Eye to accorde et cet. ${ }^{48}$

There are significant differences between the laconic nature of this text and that of Le Jeu de la Hache. One of the main stumbling blocks one has in attempting to understand it relates to the terminology used to describe various strikes and techniques. This issue is, however, present throughout the small corpus of Middle English fight books. Several words of this specialised lexis are unique to the genre and do not appear outside of it in contemporary works. ${ }^{49}$ Their singularity of appearance among surviving Middle English

\footnotetext{
${ }^{46}$ For a codicological analysis of the manuscript with a focus on the segment containing the fencing content and its relationship to the surrounding material see Geldof, 'Forewarned and Forearmed'.

47 Jaquet, 'Martial Arts by the Book', p. 44.

${ }^{48}$ London, British Library, Cotton MS Titus A XXV, fol. 105v.

49 A study of English fencing terminology has been carried out by James Hester. Hester's work, however, deals only with the most frequent and least opaque terms. See Hester, 'The Terminology of Medieval English Fight Texts: A Brief Overview'. A more recent contribution is that of Paul
} 
literature is an argument that the scribe did not want his thoughts to be easily understood, even though this extract deals with a flourish of the weapon and not interpersonal combat.

Staff weapon content in fifteenth-century fight books is, as indicated thus far, dominated by the presence of the pollaxe. With the exception of Le Jeu de la Hache, however, fight book authors rarely dedicate much space to the use of such weapons: even Talhoffer's manuscripts pale in comparison to the detail recorded in Le Jeu de la Hache. Staff weapon content in the fight books of Paulus Kal, Peter Falkner, and other late fifteenth-century sources is representative of the growing popularity of staff weapons in martial culture and military organisation. ${ }^{50}$ This pattern would go on to grow exponentially in the first half of the sixteenth century.

\section{APPEARANCES AND PATTERNS OF STAFF WEAPON USE IN SIXTEENTH-CENTURY FIGHT BOOKS}

Fight books in the first half of the sixteenth century are far more varied in their treatment of staff weapons. Armoured combat with the axe features less frequently in these later texts, a reflection of changes in contemporary martial culture. Furthermore, it is not just the variety of arms that increases but also the depth of their treatment. Nowhere is this trend more evident in the fight book genre than in the works of the Italian Pietro Monte (1457-1509), a widely-renowned condottiero who was active in the late fifteenth and early sixteenth centuries. ${ }^{51}$ Monte was the first fight book author to include lengthy treatments of the use of an exceptionally wide variety of staff weapons such as the axe, the bill, the spetum, the partisan, and different spears. What truly separates Monte's work from any other, however, is his detailed, didactic comments on the physical appearance and the many uses of these weapons. His in-depth approach and extensive comments on these subjects is a predecessor to all of the subsequent early sixteenth-century Italian treatises that record the detailed use of staff weapons as part of their own fighting system, such as in those published by Achille Marozzo (1484-1553) and Antonio Manciolino. Even though Monte was a product of the fifteenth century the humanistic approach he takes to describing martial matters is more similar - and indeed, superior - to much material produced in the sixteenth. For example, Monte goes into considerable depth describing

Wager. Wagner's approach is more ambitious than Hester's, but sometimes speculative. See Wagner, 'Common Themes in the Fighting Traditions of the British Isles'.

${ }^{50}$ For Paulus Kal's c. 1470 text see München, Bayerische Staatsbibliothek, Cgm 1507, fols 37v-42v; for Peter Falkner's c. 1495 manuscript see Wien, Kunsthistorisches Museum, MS KK5012, fols 62r65 .

51 For Monte's life see Fontaine, Le condottiere Pietro del Monte, philosophe et écrivain de la Renaissance, 1457-1509. For an overview of his military career see Brioist, 'Contextualising Pietro Monte's Military Career in Italy'. For an introduction to his literary works see Anglo, 'The Man Who Taught Leonardo Darts'. 
the appearance and use of the spetum, which he describes as a staff weapon with a long, sharpened point with two sharp wings at its base that curve upwards like a bow (although this can also describe a corseque or chauve-souris). ${ }^{52}$ Monte talks about how strong the weapon is for parrying and trapping hostile weapons and later about how it can be used not only against another spetum but also spears, jinetas, partisans, and pollaxes, the last of which has the advantage over the spetum. When discussing other means of overcoming the spetum Monte suggests wearing mail gauntlets to protect the hands from slicing cuts as well as wearing a breastplate..$^{53}$ His writing displays a forward-thinking military mind and scholarly approach that presents ideas and content in his treatises that echo the material that became popular in the decades that followed, therefore, it is not inaccurate to consider him a sixteenth century master, and by extension his treatises and material comparable and grouped with those of the early sixteenth century. ${ }^{54}$

The so-called Anonimo Bolognese is another fight book from the beginning of the sixteenth century that can be considered part of the Italian Bolognese tradition of the same period because of its overlap in the method of the transcription of the fighting system it covers as well as in the material covered in it. ${ }^{55}$ Defending and attacking are organised in numerous guards and stances and the offensive actions that counter and interact each one of them. The guards and particularly the actions are described in meticulous detail, often taking into consideration different variables and responses of the opponent. An example of this is the different actions one must undertake from a high guard (guardia alta) with the axe when the opponent aims to their head:

Finding yourself with axe in hand opposed to your enemy with your left foot forward in guardia alta [high guard], or with the right in porta di ferro stretta (narrow iron door), you will pay attention, so that your enemy wanting to offend you with some blow to the head, if you are in porta di ferro (iron door), in that tempo (moment) you will take a large step forward with your left foot, spreading your arms well outstretched, so that you receive his blow on the haft of your axe between your hands,

\footnotetext{
52 "Spetum comuniter cum puncta iacitur licet aliquas acutas aures teneat: ac revolutas in modum medii arcus anterius: que de reverso: aut sectione abscindere possunt et arma fortis". Pietro Monte, Exercitorum, fol. 34v; "The spetum usually attacks with the point, although it has a pair of sharp ears, each curbing forward like a half-bow, and able to slice with a reverse or a cut". Forgeng, Pietro Monte's Collectanea p. 126.

53 "Faciliter spetum potest contra quamcunque armam confligere. In cuius tamen oppugnantiam assumende sunt chirothece malliole de apprehensio ne propterea quod aures speti fecant". Pietro Monte, Exercitorum, fol. 34v; "The spetum can easily fight against any weapon. In opposing it we should wear mail gauntlets for holding it, since the ears of the spetum can slice". Monte, Collectanea, p. 127.

54 Monte's approach to staff weapons and staff weapon fighting can be discussed in much more detail than afforded within this article. This undertaking has, however, already been done by the authors of the present piece. See Deacon and Tzouriadis, 'Reaching Excellence'.
}

55 Roma, Biblioteca Nazionale Centrale di Roma, MSS Ravenna M-345/M-346. 
suddenly turning the heel of your axe with the left [hand] over his head, and catching his neck on the left side, you will procure to pull him strongly backward to the ground, but be aware that in your passare (pass) it is necessary that your left leg is positioned to the outside of his right side. But when you find yourself in guardia alta (high guard) as said above, and your enemy wants to offend you in the head, you will step forward with your right [foot] fending off the blow in the manner above said, and so stepping forward with the left foot, making the same turn with the heel of your axe, with all skill and force you will procure to make him fall to the ground. ${ }^{56}$

This approach and use of terminology is consistent with other works and authors from the sixteenth century that constitute the Bolognese tradition - such as Marozzo, Manciolino, Viggiani (d. 1552), and dall' Agocchie - because of their common origin and similarities. The manuscript contains several plays of the axe in full armour where both combatants use the same type of equipment. ${ }^{57}$ Additionally, the Anonimo includes a few plays with the sidesword and the two-handed sword against staff weapons. These are general instructions for the use of these swords against any staff weapon, and they focus on the approach to the fight from different guards. ${ }^{58}$

Antonio Manciolino's Opera Nova is most likely the earliest extensive printed representation of the so-called Dardi or Bolognese school. ${ }^{59}$ He presents a thorough

56 "Trovandoti con l'Accia in mano contra al tuo nemico col tuo piede manco innanzi in guardia alta, overo col destro in porta stretta di ferro, starai aveduto, percio che volendoti con alcun colpo offendere il tuo nemico la testa, passerai in quel tempo se sarai in porta di ferro, gran passo col tuo piede manco innanzi, alargando le braccia ben distese, sì che tu raccogli il suo colpo sopra l'asta de la tua Accia tra l'una et l'altra tua mano, volgendo subito con la manca il calcio de l'Accia tua sopra la sua testa et pigliatelo nel collo da la banda sinistra, ti procaccierai di tirarlo per il contrario a forza in terra, ma sij accorto, che nel tuo passare farà bisogno, che la tua gamba manca sia posta per fuori dal suo lato destro. Ma quando ti trovasti in guarda alta come è detto disopra, et volendo il tuo nemico offendere la testa tu passerai col tuo destro innanzi schermendo il colpo nel sopradetto modo, et così passerai con la manca gamba innanzi, facendo la medesma volta con il pedale de l'Accia tua, et con ogni destrezza et forza ti proccaccierai di farlo cadere in terra". MSS Ravenna M$345 /$ M-346, vol. 2, fols 24v-25r. For the translation see Jaquet, 'The plays with the axe in armour of the Anonimo Bolognese (1510-1515), p. 119.

57 MSS Ravenna M-345/M-346, vol. 2, fols 24v-27r. The armoured content certainly creates associations with the presentation of similar content from Italian fight books of the fifteenth century such as Fiore and Vadi, and its place in the wider fight book tradition has been discussed by Jaquet. See Jaquet, 'The plays with the axe in armour of the Anonimo Bolognese (1510-1515)', pp. 111-14.

${ }^{58}$ For sidesword versus staff weapons see MSS Ravenna M-345/M-346, vol. 1, fols $156^{\mathrm{v}}$ and $157^{\mathrm{r}}$. For the use of the two-handed sword versus staff weapons see MSS Ravenna M-345/M-346, vol. 2 , fol. $7 \mathrm{v}$.

59 Antonio Manciolino, Opera Nova. Manciolino’s Opera Nova was printed in 1531 and might be a revised version of an earlier edition. The earliest known surviving edition of Achille Marozzo's Opera Nova is from 1536. Jacopo Gelli mentions in his Bibliografia, however, that there was an even 
description of the use of various weapons in combat, particularly the sidesword with accompanying instruments such as the buckler, rotella and cape. His sixth book (chapter) is dedicated to the use of staff weapons. ${ }^{60} \mathrm{He}$ includes plays on the use of the partisan paired with the rotella, partisan on its own, the spiedo, the bill, and the spear. Most plays with staff weapons are performed against opponents armed with the same type of weapon. Plays and advice for the use of mixed staff weapons were also included by Manciolino, particularly regarding the use of the spear against the others. He particularly expresses how the length of the long spear is an advantage against all other staff weapons that are shorter and that its user should use the middle line (mez:o), but also, that this increased length can be a disadvantage against shorter weapons that can be used to parry the spear and close the distance between the two combatants with ease. ${ }^{61}$ The manner in which the use of the aforementioned weapons is organised is through "plays" (gioco) or "fights" (combattere). The various outcomes of specific situations resulting from these encounters are discussed alongside the optimal sequence of actions one should follow offensively and defensively with the aforementioned weapons. For example choices and branching actions in the use of the partisan are based on the target of the opponent, with the reaction, including parries and counter-attacks, being different depending on whether the opponent is aiming for the head or legs. ${ }^{62}$ The terminologies and treatment are consistent throughout Manciolino's book and they often overlap with those found in Marozzo.

Achille Marozzo's Opera Nova is not only the exemplar fight book of the Bolognese tradition but it is also arguably the most prominent fight book of the first half of the sixteenth century particularly because it is the earliest example of a nearly complete fighting system in the corpus of fight books, a status achieved through the thorough treatment of various weapons and situations in a lengthy and detailed fashion organised and grouped together in a series of motions that serve as a mnemonic device (assalti). ${ }^{63}$ Marozzo's work includes the use of weapons and unarmed combat taking into consideration the various responses to the actions he describes. The only element missing from this system is a detailed analysis of footwork and the reader is immersed into detailed complex concepts from the beginning. These are potential indications to a previous not surviving work, or to the fact that this work was geared towards experienced fencers. The fourth book (chapter) of Marozzo's Opera Nova is dedicated exclusively in the detailed

earlier edition of Marozzo’s Opera Nora from 1517. See Gelli, Bibliografia Generale Della Scherma, p.130. Jaquet and Gotti have conducted further research towards the different editions of Marozzo's Opera Nova and the potential existence of the earlier edition mentioned by Gelli. See Gotti and Jaquet, 'Two late flying prints informing on the artist involved in the Opera Nova of Achille Marozzo and on the date of an original (lost) edition?'.

60 Antonio Manciolino, Opera Nova, H2v-H7v.

61 Antonio Manciolino, Opera Nova, H7v.

62 Antonio Manciolino, Opera Nova, H4v-H5r.

63 Achille Marozzo, Opera Nova. 
treatment of staff weapons. ${ }^{64}$ The first staff weapon material covered is on the use of the partisan paired with the rotella, and with the partisan used on its own while fighting opponents using identical equipment. ${ }^{65}$ The partisan is used to parry and then deliver cuts, thrusts and glancing strikes that stem from a flow of motions. Next Marozzo covers the use of the spear and the pike, also against someone armed with the same weapons. What is particularly interesting about this passage is that the writer explicitly describes the combat of these weapons as aimed for the "soldier on foot" (da fante a piede). 66 This is an interesting distinction added to this passage for numerous reasons. The writer may have intended to focus on how he could cater for the specific needs and skills of professional soldiers, and how he understood a variety of different martial situations. More importantly it contextualises and highlights the martial context of these weapons in their contemporary military reality of use; they were the predominant weapons in contemporary warfare. Interestingly the mention to foot soldiers is not made to any of the other staff-weapon passages by Marozzo. ${ }^{67}$ Following the pike and spear the writer dedicates a few passages in the use of the spiedo. ${ }^{68}$ Subsequently, the standard bill is discussed, also in the context of use against an identical weapon. ${ }^{69}$ In contrast to the other weapons included by Marozzo the bill has technical features that allow thrusting, cutting and pulling, utilities that are all employed, usually in sequence or following a parry. Two additional small parts mention the use of the bill against the partisan. Finally, Marozzo mentions that the halberd and the axe can be used offensively and defensively in the same manner as he described regarding the standard bill, that way elevating the latter into the exemplar weapon for bladed staff weapons with multiple functions (see Fig. 5). ${ }^{70}$ This use of a single weapon to build the use of the rest of staff weapons stemming from it persisted and appeared in other fight books from the second half of the sixteenth century such as those produced by Giacomo di Grassi who mentioned the partisan as his exemplar hafted

\footnotetext{
64 Achille Marozzo, Opera Nova, cap. 179- cap. 185.

65 Achille Marozzo, Opera Nova, cap. 179- cap. 181.

66 Achille Marozzo, Opera Nova, cap. 182.
}

${ }^{67}$ The inclusion of the discussion of the pike and the spear here is an exception to the set research boundaries mentioned in the beginning of this present article. Besides the use of the weapon being different to that of the numerous sources from the fifteenth century, the inclusion of this here serves in highlighting the different context set for the use of them in the Opera Nova, in the context of its period. Further consistent analysis and research is needed for the use and inclusion of different types of spears in the corpus of fight books.

68 Achille Marozzo, Opera Nova, cap. 183.

69 Achille Marozzo, Opera Nova, cap. 184. For a discussion on the nomenclature of the bill and the choice of the "standard bill" as the preferred term see Tzouriadis "The Typology and Use of Staff Weapons in Western Europe c. 1400 - c. 1550', pp. 186-214.

70 Achille Marozzo, Opera Nova, cap. 185. This should not come as a surprise as the standard bill was extremely popular in this period particularly in Northern Italy. Troso has conducted an exhaustive diatribe on the forms and mentions of the bill in the discussed geographical and chronological context. See Troso, Le armi in asta delle fanterie europee. 
weapon. ${ }^{71}$ Marozzo is the exemplar fight book of the early sixteenth century and its roots can be traced to previous authors such as Monte, Vadi and Fiore, demonstrating a continuous (even though sometimes interrupted) martial tradition that includes a treatment of staff weapons. ${ }^{72}$ Overall, Italian fight books from the first half of the sixteenth century use a consistent terminology and vocabulary in the application of fighting and motions with staff weapons, and they clearly demonstrate alignment towards the use of weapons popular in contemporary Italy and elsewhere in Western Europe.

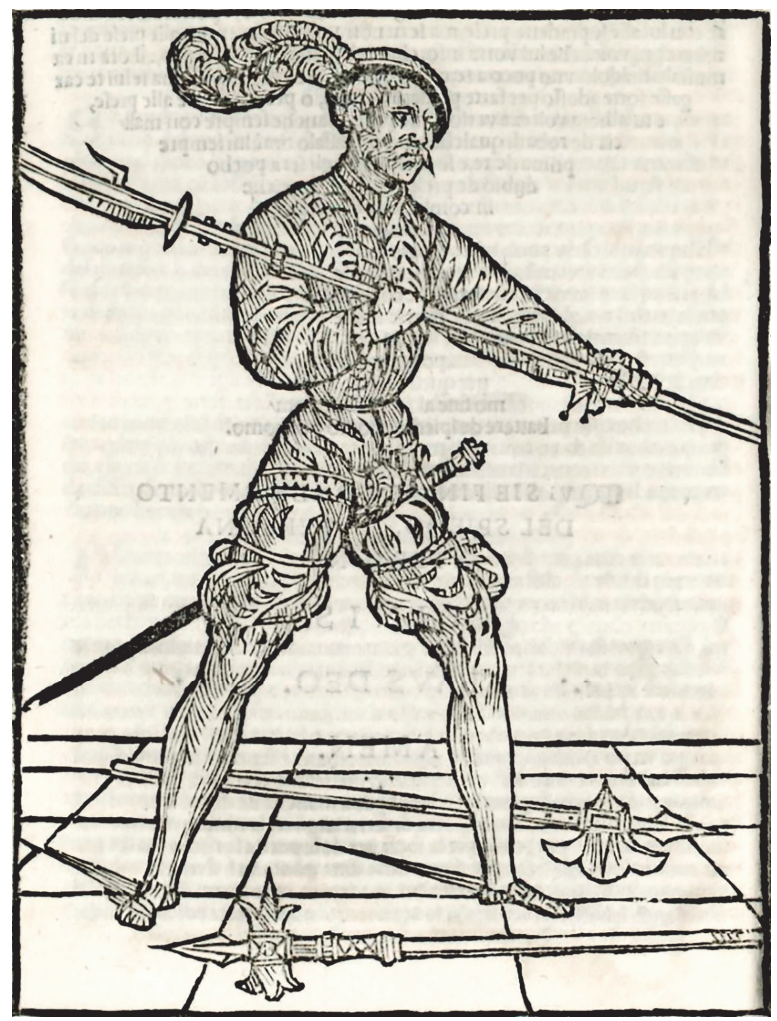

Fig 5. Woodcut from Acbille Marozio"s chapter "On the fighting with the bill one versus one" in bis Opera Nova. Notice the additional weapons on the floor, most likely linked to bis statement in Capitolo 185, wherein their manner of use is stated to be the same as the bill's. Acbille Maroz:o, Opera Nova, (Modena: Bergolae, 1536), cap. 184.

\footnotetext{
71 Giacomo di Grassi, His True Arte of Defence, trans. I. G., 04r. Even though di Grassi uses the partisan as his exemplar weapon he describes the bill as the most perfect staff weapon because it can perform any action, even though according to him the bill is not popular in war anymore. Furthermore, he treated the bill and the halberd together because they are used in the same manner which is similar to Marozzo's approach.

${ }^{72}$ Gotti, Jaquet, and Tzouriadis, European Martial Arts: from Vulcan's forge to the Arts of Mars, p. 156.
} 
Whilst staff weapon matter in fight books from the first half of the sixteenth century is largely represented in books produced within the aforementioned Bolognese tradition, a special mention needs to be made to Paulus Hector Mair (1517 - 1579), a German civil servant, fencer and collector of fight books, who even produced his own fight book, and was eventually executed for embezzling public funds. His treatment of the subject is more quantitatively comprehensive than any German text and is far lengthier than any fifteenth-century fight book. This observation can be expanded to the genre as a whole throughout the sixteenth century, and even in relation to the previously discussed Italian treatises of the same period. Mair explores a wide variety of staff weapons that were popular in his time and appear in other fight books of the fifteenth and early sixteenth centuries such as the staff, the pike, the axe, and the halberd. ${ }^{73}$ Unlike other treatises, however, Mair's includes certain staff weapons that can be considered unorthodox compared to other contemporary treatises, such as the scythe and the flail, both of which are militarised and often modified versions of plain agricultural tools (see Fig. 6). ${ }^{74}$ Their inclusion in Mair's extensively inclusive curriculum of weapons is most likely a reflection of the martial culture and situation of his period. In contrast to the staff weapons popular among professional infantry these weaponised tools were the weapons of militias and peasants. Mair was practicing martial arts and collecting fight books not long after the end of the German Peasants' Revolts (1524 1525), and his fight books' inclusion of these weapons can thus be interpreted as a reflection of the unique political and social situations that shaped certain details of his contemporary martial culture. Besides his treatment of the aforementioned staff weapons, which is done in the context of a symmetrical use where two combatants fight using the same type of equipment, Mair also covers the use of staff weapons against other weapon types. This includes fighting with the short spear, the long spear and the halberd versus the longsword, the boar spear and the dussack versus the halberd, and the sidesword versus the boar spear. ${ }^{75}$ This versatile and unorthodox study on asymmetrical fighting with staff weapons is the lengthiest in the corpus of fight books, further demonstrating the depth of Mair's work. Much like the Italian fight books from the first half of the sixteenth century, German fight books from the same period demonstrate some consistency in their treatment of staff weapons. The preferred means through which to communicate the use of staff weapons are the different versions of the spear (short spear, long spear and the pike) and the staff. These weapons form only part of the exhaustive work by Mair but they are the only staff weapons in other

\footnotetext{
73 Wien, Österreichische Nationalbibliothek, Cod.108265, fols 154r-171v for staff, pike, and halberd; for Mair's pollaxe material see Wien, Österreichische Nationalbibliothek, Cod.10826, fols 149r-155v .

${ }^{74}$ Cod.10826 6r r $^{\mathrm{r}} 14^{\mathrm{v}}$.

${ }^{75}$ Cod.10826, fols $13^{\mathrm{r}}-13^{\mathrm{v}}, 15^{\mathrm{r}}-15^{\mathrm{v}}, 19^{\mathrm{r}}-19^{\mathrm{v}}, 120^{\mathrm{v}}-121^{\mathrm{v}}$.
} 
examples such as the fight books of Andre Paurñfeyndt or MS Bestand 7020.76 Most German fight books from this period lack the staff weapon pluralism of Mair's works.

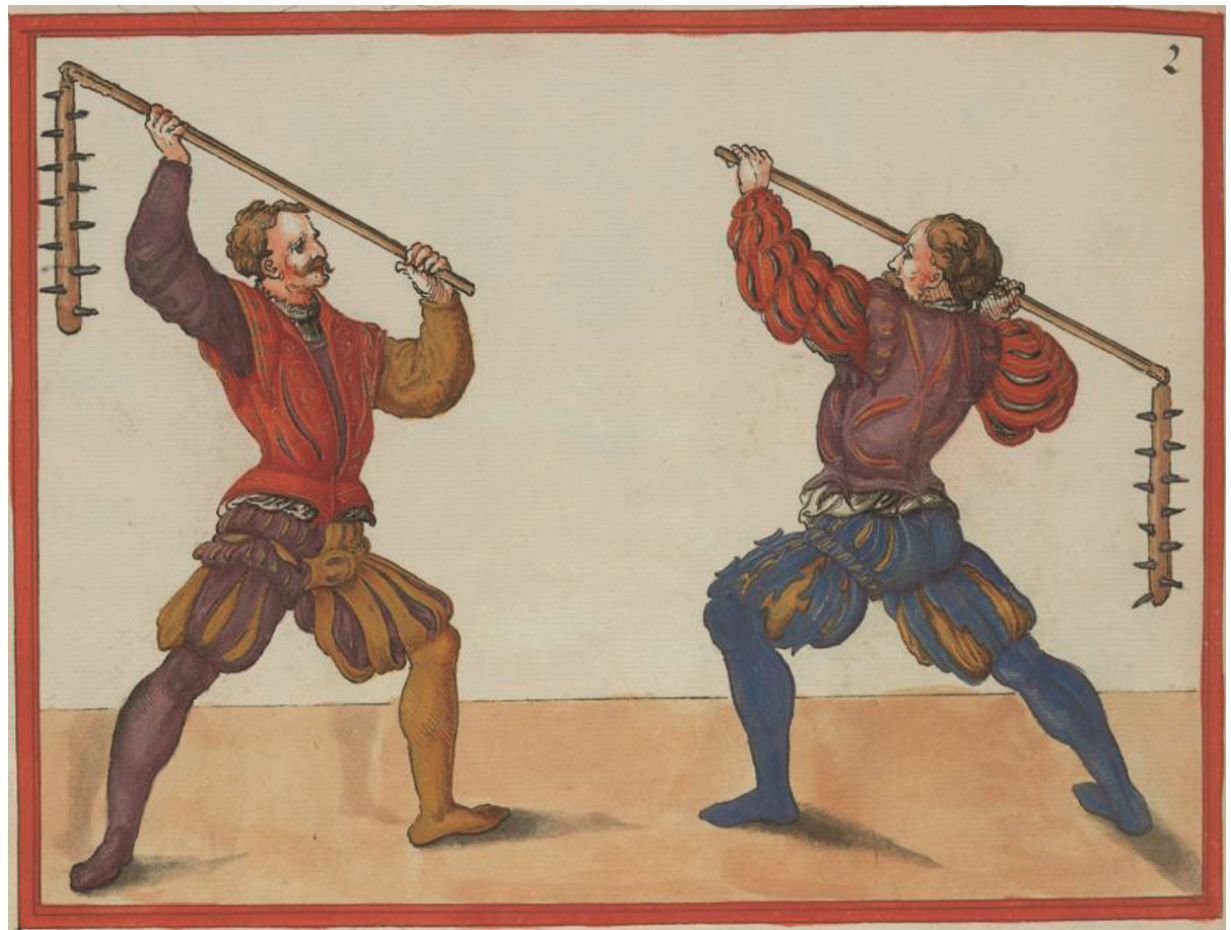

Fig. 6. Two combatants fencing with flails. Paulus Hector Mair, Opus Amplissimum de Arte Athletica, c. 1540, Dresden, Säcbsiche Landesbibliothek, Mscr.Dresd.C.93/94 1 Mscr.Dresd.C.93, fol. 219".

Overall, fight books with staff weapon matter from the first half of the sixteenth century present certain significant differences to their fifteenth century counterparts. With the exception of certain fight books like the Anonimo, armoured axe combat slowly disappeared. The use of the axe usually persisted in the simple mention of the weapon in certain fight books or was not included at all in most cases. Exceptions to this include Monte and Anonimo. Armoured combat and the artistic representation of the combatants gave way nearly exclusively to unarmoured combat, which is a testament to the changing clientele of fencing masters, often already represented by the medium of the fight book which shifted from custom manuscripts to printed books. ${ }^{77} \mathrm{New}$ weapons such as the spiedo, the partisan, the pike, and repurposed agricultural tools made their way into the

76 Andre Paurñfeyndt, Ergrundung Ritterlicher Kunst der Fecbterey, pp. 59-65; Köln, Historisches Archiv, MS Best.7020 (W*) 150, fols 20v-22r.

77 Jaquet, 'European Fight Books 1305-1630', pp. 5-24. 
pages of fight books following the rapidly changing trends in their contemporary warfare and martial realities.

\section{CONCLUSION}

Staff weapons would continue to make appearances in fight books throughout the second half of the sixteenth century and well into the seventeenth. They also remained popular choices for the individuals who penned these works. The gentleman George Silver, for example - who penned his Paradoxes of Defence in 1599 - wrote that "if we will have this true Defence, we must seeke it where it is, in short swords, short staves, the halfe pike, partisans, gleves, or such like weapons". ${ }^{78}$ The clear quantitative superiority of staff weapons in this list is indicative of the high regard in which they were held by Silver, who took this even further by arguing that staff weapons such as the axe, halberd, and bill were more advantageous than the two-handed sword, sword and buckler, sword and target, sword and dagger, and the rapier and poniard. ${ }^{79}$ Eighteen years later another Englishman, Joseph Swetnam (d. 1621), voiced similar claims regarding the staff in that "there is great oddes in the Staffe" when used against an opponent carrying a rapier and dagger. ${ }^{80}$ Much like the previously mentioned di Grassi's publication from the same year, Joachim Meyer's (d. 1571) 1570 fight book also includes an in-depth treatment of staff weapons such as the staff, the pike and the halberd. The last two weapons are primarily associated with infantry warfare, and their treatment and inclusion shows the ongoing adaptability of fencing masters and their use of weapons in different martial contexts (affected by their use on the field, staff weapons were repurposed in the fencing hall). ${ }^{81}$

This transnational adaptability and inclusion of staff weapons did not stop with the end of the sixteenth century. In the first half of the seventeenth century, two of the four books written by the Italian fencing master Francesco Fernando Alfieri were dedicated to exclusively performing drill using a pike and a flag respectively, indicating how fight book authors continued to deal with the use of staff weapons whilst simultaneously adopting ongoing martial trends. ${ }^{82}$ Moreover, a new trend can be observed in the works from seventeenth-century authors: the use of staff weapons for martial demonstration and display in a manner that resonates the parade weapon drills that have persisted until today. Alfieri, for example, made the distinction between the use of the pike for military purposes and for "games" (drills) very clear. ${ }^{83}$ Most notably, Johann Georg Pascha (16281678) produced, initially in German and then translated to French, a work on saluting,

\footnotetext{
${ }^{78}$ George Silver, Paradoxes of Defence, A4.

${ }^{79}$ George Silver, Paradoxes of Defence, pp. 30-32.

80 Joseph Swetnam, The Schoole of the Noble and Worthy Science of Defence, p. 148.

81 Joachim Meyer, Gründtliche Beschreibung der Kunst des Fechtens.

${ }^{82}$ Francesco Fernando Alfieri, La Bandiera; Francesco Fernando Alfieri, La Picca.

83 Alfieri, La Picca, cap. 3.
} 
fighting, and making flourishes with the flag, the pike, the half-pike, and the partisan. ${ }^{84} \mathrm{It}$ is worth noting that in the case of the partisan its use is divided up into marching, defending, and flourishing with it. ${ }^{85}$ It is the part of the work describing the use of the half-pike, however, where the discussion begins with the merits of the weapon as a tool for self-defence in a civic environment against many opponents and the scenarios in which it can be used; it then progresses to discussing techniques and flourishes. ${ }^{86}$ Indeed, there is clearly much left to be said on the appearances, uses, and perceptions of staff weapons in fight books dating from the late sixteenth and seventeenth centuries.

The changes in warfare that occurred throughout the fifteenth and sixteenth centuries included significant organisational shifts in the nature of military forces such as the establishment of standing armies in France, Burgundy, and some Italian states. ${ }^{87}$ This, alongside the addition of the increasing use of professional mercenaries and the extensive introduction of military services, shifted warfare towards practices that relied on these professional and semi-professional soldiers and away from the conventional ideas of guerre nobilitaire. Whereas fight books and the contexts of using the axe can be widely (but not exclusively) associated with martial elites in the fifteenth century, fencing schools that became increasingly popular from the early sixteenth century, particularly those in Italy, were geared towards a wider civic audience and the fight books produced for these audiences include the more varied content regarding staff weapons that were closely associated with their contemporary conduct of war and the existing culture cultivated in civic environments. These shifts and changes in the popularisation of martial culture, especially in urban spaces, went hand to hand with changes in warfare and their link can be observed throughout the period examined here. That is not to say that these changes in the content of fight books or martial culture in the cities where fencing schools thrived suddenly appeared in the early sixteenth century; such schools and even fencing guilds were active across European cities from the fourteenth century and would flourish in the fifteenth. Social changes and growing levels of social mobility in the early sixteenth century accelerated the accessibility and shift of their audience from the established aristocracy to civilian members of society who could afford martial training either as a leisure activity or because of the martial-social necessities of their social status. ${ }^{88}$ This is

${ }^{84}$ Johann Georg Pascha, Deutliche Beschreibung Unterschiedener Fabnen-Lectionen. Olivier Dupuis has produced an in-depth critical translation and analysis of the staff material in the French editions of Pascha. This interlingual research, often addressing the relationship of the French and German technical vocabulary in Pascha's work, is invaluable when researching the content and purpose of Pascha's writings, particularly regarding solo drills and salutations that were meant to be performed in front of an audience. See Dupuis, 'The French Staff Material from Johann Georg Pasch', pp. 6465.

85 Pascha, Deutliche Beschreibung Unterschiedener Fabnen-Lectionen, pp. 172-213.

86 Pascha, Deutliche Beschreibung Unterschiedener Fahnen-Lectionen, pp. 214-243.

87 Malcolm Vale, War and Chivalry, p. 147.

88 Daniel Jaquet, 'Fighting in the Fightschools', pp. 49-50. 
perhaps why the appearances of staff weapons in fight books are the best portrayal of their contemporary martial context from a social-historical perspective within the genre: the quantitative and qualitative representation of this weapon shifts to match and adapt to many of the external military and social changes that shaped the martial culture of fifteenth- and sixteenth-century Europe.

For now, however, the present article has said much of the appearance and uses of staff weapons in fifteenth- and early sixteenth-century fight books. It has first of all drawn attention to several of the problems that arise when one begins to consider the subject of staff weapons, whether these be related to problems encountered in the sources themselves or inconsistencies in modern scholarship. More importantly, it has established a pattern of staff weapon appearances in the fight book genre that corresponds to changing facets of martial and military culture, namely in the early dominance of the pollaxe as used in armour. As weapons such as the partisan, the bill and the halberd became increasingly popular, if not necessary, in the military and martial-civic contexts of sixteenth century Europe their appearance in contemporary fight books became recurring. This article has also shown how the use of individual staff weapons such as axes are often characterised in comparison either to other staff weapons or even swords. It has, finally, indicated how by focusing on staff weapons, researchers can create a valuable microcosm through which to analyse the wider fight book corpus, a useful tool given the heterogeneous nature of the genre.

\section{BIBLIOGRAPHY}

\section{V.1. Primary sources}

Agrippa, Camillo, Tratto di Scientia d'Arme, con un Dialogo di Filosofia (Roma: Blado, 1553)

Alfieri, Francesco Fernando, La Bandiera di Francesco Fernando Alfieri (Padova: Sardi, 1638)

L La Picca di Francesco Fernando Alfieri (Padova: Sardi, 1641)

dall'Agocchie, Giovanni, Dell'arte di scrimia libri tre: ne' quali breuemente si tratta dell'arte dello schermire, della giostra dell'ordinar battaglie: opera necessaria a capitani, soldati, \& a qual si noglia gentil'buomo (Venezia: Tamborino, 1572)

Dorchester, Dorset History Centre, DC/BTB/FG/3

Dresden, Sächsiche Landesbibliothek, Mscr.Dresd.C.93/94 1 Mscr.Dresd.C.93

Dresden, Sächsiche Landesbibliothek, Mscr.Dresd.C.93/94 2 Mscr.Dresd.C.94

Grassi, Giacomo di, His True Arte of Defence, trans. I. G. (London: Iaggard, 1594)

The Inventory of King Henry VIII: The Transcript, ed. by David Starkey et al. (London: Miller, 1998)

Købnhavn, Det Kongelige Bibliotek, MS Thott.290.2 
Köln, Historisches Archiv, MS Best.7020 (W*) 150

London, British Library, Cotton MS Titus A XXV

Los Angeles, J Paul Getty Museum, MS Ludwig XV 13

Manciolino, Antonio, Opera Nova (Venezia, Zoppino, 1531)

Marozzo, Achille, Opera Nova (Modena: Bergolae, 1536)

Meyer, Joachim, Gründtliche Bescbreibung der Kunst des Fechtens (Strasbourg: Berger, 1570)

Monte, Pietro, Exercitorum atque artis militaris collectanea in tris libros distincta (Milano: Scinzenzlar, 1509)

_ Pietro Monte's Collectanea: The Arms, Armour and Fighting Techniques of a FifteenthCentury Soldier, trans. Jeffrey L. Forgeng (Woodbridge: Boydell, 2018)

München, Bayerische Staatsbibliothek, Cgm 558

München, Bayerische Staatsbibliothek, Cgm 1507

München, Bayerische Staatsbibliothek, Cod.icon 394a

Nürnberg, Germanisches Nationalmuseum, Hs. 3227a

Paris, Bibliothèque nationale de France, MS Français 1996

Pascha, Johann Georg, Deutliche Beschreibung Unterschiedener Fabnen-Lectionen: In Acbt Spiel eingetheilet/ Nebst dem Piquen-Spiel/ Pertuisan und halben Piquen/ oder Jägerstock (Hall in Sachsen: Oelschlegeln, 1673)

Paurñfeyndt, Andre, Ergrundung Ritterlicher Kunst der Fecbterey (Wien: Vietor, 1516)

Roma, Biblioteca Nazionale Centrale di Roma, MSS Ravenna M-345/M-346

Roma, Biblioteca Nazionale Centrale di Roma, MS Vitt.Em.1324

Silver, George, Paradoxes of Defence (London: Blount, 1599)

Swetnam, Joseph, The Noble and Worthy Schoole of Defence (London: Okes, 1617)

Viggiani, Angelo, Lo schermo d'Angelo Viggiani dal Montone da Bologna: nel quale per via di dialogo si discorre intorno all'eccellenza dell'armi, \& delle lettere: intorno all'offesa \& alla difesa: \& s'insegna uno schermo di spada sola da filo, co'l quale può l'buomo non pure difendersi da qual si uoglia colpo del nimico, ma anchora offender lui non poco (Venezia: Angelieri, 1575)

Wien, Kunsthistorisches Museum, MS KK5012

Wien, Österreichische Nationalbibliothek, Cod.10825

Wien, Österreichische Nationalbibliothek, Cod.10826

\section{V.2. Secondary literature}

Anglo, Sydney, 'Anglo-Burgundian Feats of Arms, Smithfield, June 1467', Guidhall Miscellany, 2 (1965), 271-83

'Le Jeu de la Hache: A Fifteenth-Century Treatise on Chivalric Axe Combat', Archaeologia, 109 (1991), 113-28 
'The Man Who Taught Leonardo Darts: Pietro Monte and his Lost Fencing Book', Antiquaries Journal, 69 (1989), 261-78

The Martial Arts of Renaissance Europe (New Haven and London: Yale University Press, 2000)

Blair, Claude, European and American Arms: c. 1100-1850 (New York: Crown Publishers, 1962)

Brioist, Pascal, 'Contextualising Pietro Monte's Military Career in Italy', Acta Periodica Duellatorum, 7 (2019), 217-27

Burkart, Eric, 'Limits of Understanding in the Study of Lost Martial Arts:

Epistemological Reflections on the Mediality of Historical Records of Technique and the Status of Modern (Re-)Construction', Acta Periodica Duellatorum, 4/2 (2016), 5-30

Burkart, 'The Autograph of an Erudite Martial Artist: A Close Reading of Nuremberg, Germanisches Nationalmuseum, Hs. 3227a', in Late Medieval and Early Modern Fight Books: Transmission and Tradition of Martial Arts in Europe (14th - 17th Centuries), ed. by Daniel Jaquet, Karin Verelst, and Timothy Dawson (Leiden: Brill, 2016), pp. 451-80

Contamine, Philippe, Guerre, état et sociétè à la fin du Moyen Age (Paris: Mouton, 1972) Curry, Ann and Michael Hughes, eds, Arms, Armies and Fortifications in the Hundred Years' War (Woodbridge: Boydell, 1999)

Deacon, Jacob Henry, 'Prologues, Poetry, Prose and Portrayals: The Purposes of Fifteenth-Century Fight Books', Acta Periodica Duellatorum, 4/2 (2016), 69-90

— and Iason-Eleftherios Tzouriadis, 'Reaching Excellence: Staff Weapon Typologies, Contexts, and Fighting Techniques in the Collectanea of Pietro Monte', Acta Periodica Duellatorum, 7 (2019), 235-54

Deutscher, Lisa, Mirjam Kaiser, and Sixt Wetzler, eds, The Sword: Form and Thought (Woodbridge: Boydell, 2019)

Dupuis, Oliver, 'The French Staff Material from Johann Georg Pasch', Acta Periodica Duellatorum, 4/1 (2016), 53-101

and Vincent Deluz, 'Le Jeu de la Hache: A Critical Edition and Dating Discussion', Acta Periodica Duellatorum, 5/1 (2017), 3-62

Eco, Umberto, On Ugliness (London: Harvill Secker, 2007)

Ellehauge, Martin, Certain Phases in the Origin and Development of the Glaive (København: Norlundes Bogtrykkeri, 1945)

Fontaine, Marie-Madeleine, Le condottiere Pietro del Monte, philosophe et écrivain de la Renaissance, 1457-1509 (Genève and Paris: Slatkine, 1991)

Forgeng, Jeffrey L., 'Owning the Art: The German Fechtbuch Tradition', in The Noble Art of the Sword: Fashion and Fencing in Renaissance Europe, ed. by Tobias Capwell (London: Wallace Collection, 2012), pp. 165-75 
Geldof, Mark Ryan, 'Forewarned and Forearmed: Contents of BL, Cotton MS. Titus A. XXV, ff. 94-105', The Electronic British Library Journal, 2014, <https://www.bl.uk/eblj/2014articles/pdf/ebljarticle32014.pdf> [last accessed 19 February 2020]

Gelli, Jacopo, Bibliografia Generale Della Scherma: Con Note Critiche, Biografiche E Storiche. Bibliographie Générale de L'escrime: Avec Notes Critiques, Biographiques et Historiques, 2nd ed. (Milano: Hoepli, 1895)

Gotti, Roberto, Daniel Jaquet and Iason-Eleftherios Tzouriadis, European Martial Arts: from Vulcan's forge to the Arts of Mars (Botticino: Gairethinx, 2019)

and Daniel Jaquet, 'Two late flying prints informing on the artist involved in the Opera Nova of Achille Marozzo and on the date of an original (lost) edition?', Acta Periodica Duellatorum, 4/1 (2016), 213-20

Grotkamp-Schepers, Barbara, Isabell Immel, Peter Johnsson, and Sixt Wetzler, Das Schwert: Gestalt und Gedanke (Solingen: Deutsches Klingenmuseum, 2015)

Hale, John R., Artists and Warfare in the Renaissance (New Haven: Yale University Press, 1990)

Hall, Bert S., Weapons and Warfare in Renaissance Europe: 1450-1620 (Baltimore: Johns Hopkins University Press, 1985)

Hester, James, 'The Terminology of Medieval English Fight Texts: A Brief Overview', in "Can These Bones Come to Life?" Insights from Reconstruction, Reenactment, and Re-creation. Volume 1: Historical European Martial Arts, ed. by Ken Mondschein (Wheaton: Freelance Academy Press, 2014), pp. 70-79

Jaquet, Daniel, 'Fighting in the Fightschools Late XVth, Early XVIth Century', Acta Periodica Duellatorum, $3 / 2$ (2015), 47-66

'Martial Arts by the Book: Historical European Martial Arts', in The Martial Arts Studies Reader, ed. by Paul Bowman (London: Rowman \& Littlefield, 2018), pp. 41-54 'The Plays with the Axe in Armour of the Anonimo Bolognese (1510-1515)', Acta Periodica Duellatorum, 5/1 (2017), 109-30

'European Fight Books 1305-1630: Classification, typology and comparison between manuscripts and prints (1510-1515)', Acta Periodica Duellatorum, 8/1 (2020), $5-25$

Kleinau, Jens Peter, 'Visualised Motion: Iconography of Medieval and Renaissance Fencing Books', in Late Medieval and Early Modern Fight Books: Transmission and Tradition of Martial Arts in Europe (14th - 17th Centuries), ed. by Daniel Jaquet, Karin Verelst and Timothy Dawson (Leiden: Brill, 2016), pp. 88-116

Mallet, Michael Edward, and Christine Shaw, The Italian Wars, 1494-155: War, State and Society in Early Modern Europe (New York: Routledge, 2014)

Moffat, Ralph Dominic, 'The Medieval Tournament: Chivalry, Heraldry and Reality. An Edition and Analysis of Three Fifteenth-Century Tournament Manuscripts' (unpublished doctoral thesis, University of Leeds, 2010) 
Mondschein, Ken, 'The Italian Schools of Fencing: Art, Science, and Pedagogy', in Late Medieval and Early Modern Fight Books: Transmission and Tradition of Martial Arts in Europe (14th - 17th Centuries), ed. by Daniel Jaquet, Karin Verelst and Timothy Dawson (Leiden: Brill, 2016), pp. 280-324

Nicholson, Helen, Medieval Warfare: Theory and Practice of War in Europe 300-1500 (Basingstoke: Palgrave, 2004)

Oakeshott, Ewart, European Weapons and Armour: From the Renaissance to the Industrial Revolution (Woodbridge: Boydell, 2012)

Planche, Alice, 'Du tournoi au théâtre en Bourgogne. Le Pas de la Fontaine des Pleurs à Chalon-Sur-Saòne, 1449-1450', Le Moyen Age: Revue d'bistoire et de philologie, 81.1 (1975), 97-128

Richardson, Thom, 'The Bridport Muster Roll of 1457', in Medieval Warfare 1300-1450, ed. by Kelly DeVries (London: Routledge, 2010), pp. 149-55

Rimer, Graeme. 'Weapons', in Blood Red Roses: The Archaeology of a Mass Grave from Towton $A D$ 1461, ed. by Veronica Fiorato, Anthea Boylston, and Christopher Knüsel (Oxford: Oxbow, 2002), pp. 119-29

Stone, George Cameron, A Glossary of Construction, Decoration and Use of Arms and Armor in All Times Together With Some Closely Related Subjects (New York: Jack Brussel, 1961)

Strickland, Matthew, ed., Armies, Chivalry and Warfare in Medieval Britain and France:

Proceedings of the 1995 Harlaxton Symposium (Stamford: Paul Watkins, 1988)

Tlusty, B. Ann, The Martial Ethic in Early Modern Germany: Civic Duty and the Right of Arms (New York: Palgrave Macmillan, 2011)

Troso, Mario, Le armi in asta: Delle fanterie europee (1000-1500) (Novara: Instituto Geografico De Agostini, 1988)

Tzouriadis, Iason-Eleftherios, 'The Typology and Use of Staff Weapons in Western Europe: c. 1400 - c. 1550' (unpublished doctoral thesis, University of Leeds, 2017)

'The Foot Combat as Tournament Event: Equipment, Space and Forms', in The Medieval Tournament as Spectacle: Tourneys, Jousts and Pas d'Armes, 1100-1600, ed. by Alan V Murray and Karen Watts (Woodbridge: Boydell, 2020), pp. 155-84.

Vale, Malcolm, War and Chivalry: Warfare and Aristocratic Culture in England, France and Burgundy at the End of the Middle Ages (London: Ducksworth, 1981)

Wagner, Paul, 'Common Themes in the Fighting Tradition of the British Isles', in Late Medieval and Early Modern Fight Books: Transmission and Tradition of Martial Arts in Europe (14th - 17th Centuries), ed. by Daniel Jaquet, Karin Verelst and Timothy Dawson (Leiden: Brill, 2016), pp. 410-48

Waldman, John, Hafted Weapons in Medieval and Renaissance Europe: The Evolution of European Staff Weapons Between 1200 and 1650 (Leiden: Brill, 2005) 